\title{
COL11A1 wt Allele
}

National Cancer Institute

\section{Source}

National Cancer Institute. COL11A1 wt Allele. NCI Thesaurus. Code C75314.

Human COL11A1 wild-type allele is located in the vicinity of 1 p21 and is approximately $232 \mathrm{~kb}$ in length. This allele, which encodes collagen alpha-1(XI) chain protein, plays a role in modulation of cartilage structure. Mutations in the gene are associated with both Stickler syndrome type 2 and Marshall syndrome. 